\title{
The Bibliometric Qualities of Original Research Published in the Eurasian Journal of Emergency Medicine between the Years 2010-2014
}

\author{
Mücahit Emet ${ }^{1}$, Illker Akbaş ${ }^{1}$, Abdullah Osman Koçak', Başar Cander², Şahin Aslan \\ 'Department of Emergency Medicine, Atatürk University School of Medicine, Erzurum, Turkey \\ ${ }^{2}$ Department of Emergency Medicine, Necmettin Erbakan University School of Medicine, Konya, Turkey
}

\begin{abstract}
Aim: Bibliographic work in the Turkish emergency medicine community is very scarce. We aim to improve upon the shortcomings in this area.

Materials and Methods: Original research published in the Eurasian Journal of Emergency Medicine (EAJEM) (formerly known as the Academic Journal of Emergency Medicine) within the 5-year period between 2010 and 2014 was retrospectively reviewed.

Results: While retrospective publications stood out the most $(n=81,54.7 \%)$, they were followed by prospective $(n=38,25.7 \%)$ and sectional $(n=29,93.9 \%)$ works. A vast majority of the work was concentric $(n=139,93.9 \%)$. Here $6.1 \%$ publications were sourced overseas. The most commonly studied subjects in the articles published in the EAJEM were medical emergencies (26.35\%), trauma (20.27\%), and emergency service (19.59\%). Further, $52.7 \%(n=78)$ texts were written in English and 47.3\% ( $n=70)$ were written in Turkish. In 15.5\% ( $n=23)$ articles, an emergency medicine resident and/or emergency medicine specialist was not among the authors. The original research most commonly had 3 keywords ( $n=73,49.3 \%$ ). There were $12(8.1 \%)$ articles in which no tables were used and $70(47.3 \%)$ articles in which there were no figures. According to our findings, a total of 2981 references were used in the 148 articles that were reviewed, and the median reference value per article was 17 (min: 6; max: 50). In our study, 38 references were self-references (12.85) and 727 (24.4\%) references were references to texts published in journals in the Turkish index. Within all the references, there were $43(14.4 \%)$ references to the Turkish Journal of Emergency Medicine (TJEM), 41 (13.8\%) references to the EAJEM, and only 3 (1.1\%) references to Journal of Emergency Medicine Case Reports (JEMCR). The median value of references made to texts in the journals in the Turkish index per article was 2 ( $\min : 0$; max: 32). The number of references to the TJEM per article was $43 / 148(29.1 \%)$, that to the EAJEM was $41 / 148(27.7 \%)$, and that to JEMCR was $3 / 148(2 \%)$. While the acceptance period ranged between 1 and 350 days, the average period was 49 days.
\end{abstract}

Conclusion: We believe that preference should be given to the printing of prospective and multi-centric publications and those with more keywords. Keywords: Bibliometrics, Eurasian Journal of Emergency Medicine, original research, article

\section{Introduction}

The Academic Journal of Emergency Medicine is the international, scientific, and official publication of the Emergency Medicine Physicians Association of Turkey, based on the principles of independent and unprejudiced peer review. The journal underwent restructuring in the year 2015 and continued on its publications in the scientific arena as the Eurasian Journal of Emergency Medicine (EAJEM). The first issue of the journal was published in 2003 (1). Since 2007, it has been being published quarterly, in the months of March, June, September, and December. Information regarding the process of the uploading of scientific papers and the evaluation and acceptance of papers can be found at the Web address www.eajem.com (2).

Bibliometrics is the statistical investigation of scientific publications in a certain subject and within a certain time period with respect to the subject, author, referenced author, and referenced sources, and it reveals the general structure of a particular discipline based on the obtained statistical results (3). Bibliometrics can simply be called the statistical analysis of publications. Bibliometric analyses can be of a definitive quality, such as determining the number of articles published in a particular year, or they can be evaluative, such

Correspondence to: Mücahit Emet e-mail: mucahitemet@gmail.com 
as doing a reference analysis in order to reveal in what way an article has influenced articles succeeding it (4).

Unfortunately, studies based on the analytical evaluation of scientific articles published in periodicals in our country are extremely rare. Such research is of paramount importance in terms of determining the tendencies, content, and effects of scientific journals in a country (5).

In this bibliometric study, our aim is to map out the publication of original articles in the Academic Journal of Emergency Medicine (now, EAJEM) within the 5-year period between 2010 and 2014.

\section{Materials and Methods}

All the published issues of EAJEM within the 5-year period between 2010 and 2014 are available online at the Web address http:// www.eajem.com/eng/arsiv/archive. All printed publications were examined. For articles opened in the PDF format, if the text "original article" was present in the upper left corner in the information regarding the type of article, it was included in this study. For each examined article, the following parameters were recorded and calculated: the year; issue; language; number of authors; how many of the authors worked at the emergency service; rank of the responsible author; which region of Turkey the corresponding author is from; number of keywords in the abstract; study design; number of centers where the study was done; whether it is an experimental study or not; the topic of the article; number of tables, figures, and references in the article; the acceptance period of the articles; whether any of the authors made a reference to his/her own texts in the article; number of references to journals in the Turkish index; and number of references to the Journal of Emergency Medicine Case Reports (JEMCR), Turkish Journal of Emergency Medicine (TJEM), and EAJEM.

The topics of the texts were grouped under 7 main headings: trauma, intoxication, medical emergencies, surgical emergencies, pharmaceutical studies, disaster medicine, and emergency service. Articles included under the heading of emergency services were related to training, management, security, cost, patient satisfaction, demographics of the admitted patients, hospital organization, and emergency medical system.

The study design data were accepted as stated in the materials and methods section of the article being investigated.

The journals listed on the Web page http://www.atifdizini.com/ journals/tr-index.html of the Turkish Citation Index were accepted as the Turkish index, and the journal citations in this list were grouped as the Turkish index citations.

Exclusion criteria for the articles: Articles written before 2010; articles written during 2015; and work that is not in the original research category, such as case reports, letters to the editor, letters, reviews, meeting reports, questions, and images, were excluded from the analyses.

\section{Statistical analysis}

Data were entered into the Statistical Package for the Social Sciences (IBM SPSS Statistics, Armonk, NY, USA) version 20.0. Data were represented as percentage, mean $\pm S D$ (for normally distributed data), and median (for data that did not conform to the normal distribution). The chi-square test was used in the comparison of percentages, and the Student's t-test or Mann-Whitney $U$ test were used in the comparison of mean values. Here, $p<0.05$ was considered significant.

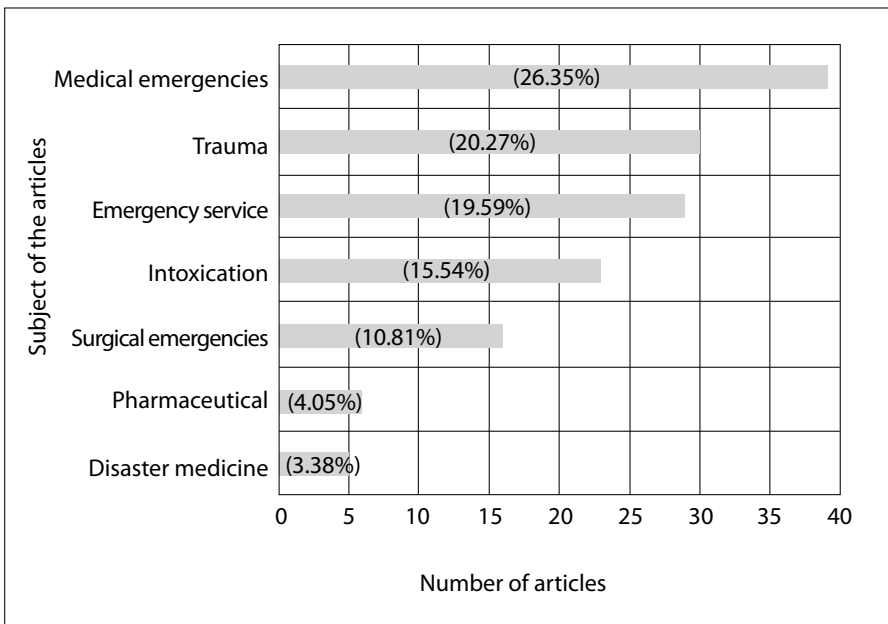

Figure 1. Distribution by subject of articles published between 2010 and 2014 in the EAJEM

\section{Results}

A total of 148 original studies carried out in the 5-year period between 2010 and 2014 were included in this study: out of these, 23 (15.5\%) were from 2010; 27 (18.2\%), 2011 ; 34 (23\%), 2012; 32 (21.6\%), 2013; and 32 (21.6\%), 2014. The issues were printed quarterly. A total of 20 journals were examined in this study. The median number of articles per journal was 7 (min: 5; max: 9).

A total of 9 articles were from abroad (6.1\%). The ratio of the citation of articles published in journals in the Turkish index by articles from abroad was significantly lower than that for domestic citations $(0.2 \pm 0.7$ vs. $5.2 \pm 6.3, p<0.001)$. There was no significant difference ( $64 \pm 56$ vs. $66.6 \pm 53.9, p=0.893)$ in terms of the period of acceptance between domestic articles and those sent from abroad.

When the research types were examined, retrospective publications ( $n=81,54.7 \%)$ stood out the most, while prospective $(n=38$, $25.7 \%)$ and sectional $(n=29,19.6 \%)$ publications were fewer. A vast majority of the research was concentric $(n=139,93.9 \%)$, while the number of studies with two or more centers was 9 (6.1\%). Only $4(2.7 \%)$ studies were experimental. The ratio of journal citations recorded in the Turkish index in the prospective studies was significantly lower as compared to those in retrospective articles $(1.7 \pm 2.8$ vs. $6.5 \pm 7.1, \mathrm{p}<0.001)$. The distribution of articles by subjects is shown in Figure 1.

The distribution of articles by region is as follows. Marmara: 14.2\% ( $n=21)$; Aegean: 7.4\% $(n=11)$; Central Anatolia: $25 \%(n=37)$; Mediterranean: $15.5 \%(n=23)$; the Black Sea: $9.5 \%(n=14)$; Eastern Anatolia: $6.1 \%(n=9)$; Southeast: $16.2 \%(n=24)$; and overseas: $6.1 \%$ $(n=9)$ (Figure 2). Articles sent from Northern Cyprus were categorized as overseas.

In this study, 52.7\% ( $n=78)$ articles were written in English and $47.3 \%(n=70)$ were written in Turkish. No Turkish publications have been published after 2014. About a third of the articles published each year between 2010 and 2013 were written in English. In 2013, the Turkish-English ratio was 1:1. The ratio of references to scientific articles published in journals in the Turkish index in the Turkish articles was significantly higher when compared to articles written in English (6.9 \pm 6.9 vs. $3.2 \pm 4.9, \mathrm{p}<0.001)$.

The distribution of the number of authors is shown in Figure 3; at $26.4 \%$, articles written by a total of 6 authors were the most com- 


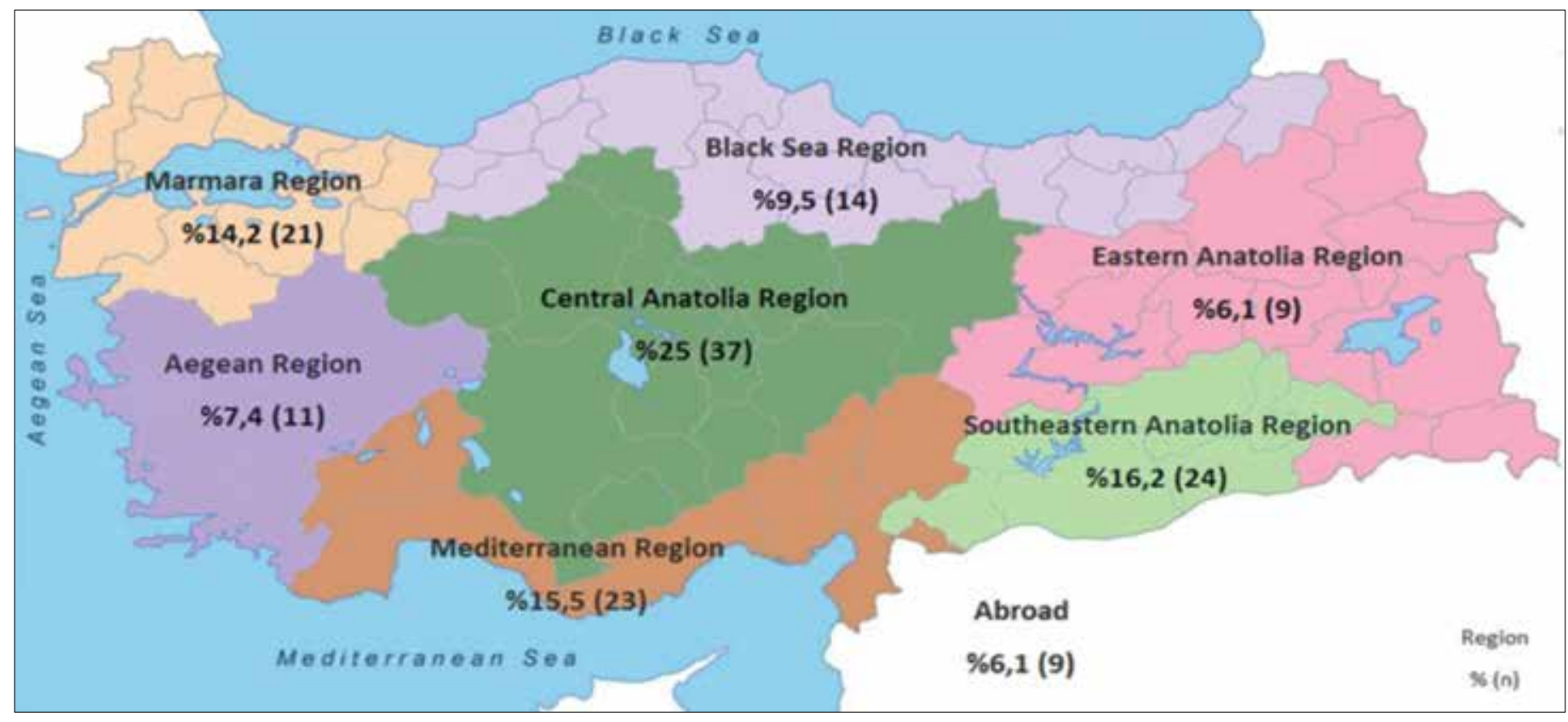

Figure 2. Distribution by region of original articles printed between 2010 and 2014 in the EAJEM. Region \% (n)

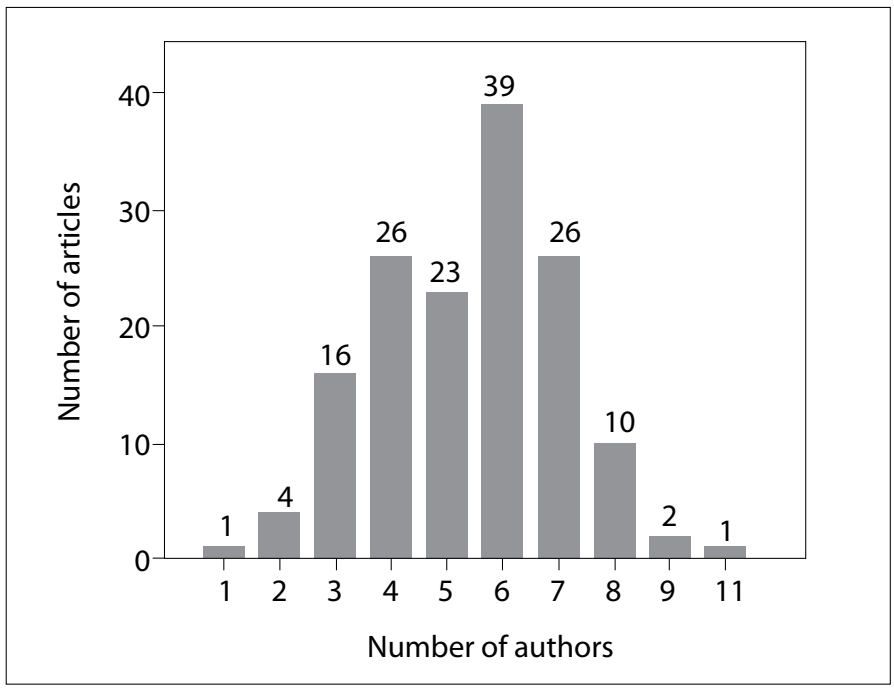

Figure 3. Distribution by number of authors of articles published between 2010 and 2014 in the EAJEM

mon. This was followed by articles with 4 and 7 authors (17.6\%). The percentage of articles with 5 authors was $15.5 \%$.

In $15.5 \%(n=23)$ articles, there were no emergency medicine residents and/or emergency medicine specialists among the authors. The design of these studies was mostly retrospective $(73.9 \%, n=17)$. The ratio of references to the Turkish index per article in these papers $(8.9 \pm 1.87)$ was higher $(p=0.028)$ as compared to studies in which there was at least one emergency doctor. However, the total number of references to the Turkish emergency medicine journals per article (JEMCR references + TJEM references + EAJEM references) was lower $(p=0.045)$ in articles with no emergency doctors among its authors $(0.21 \pm 0.59)$ as compared to studies with at least one emergency doctor among its editorial staff $(0.65 \pm 1)$.

In $72.3 \%(n=107)$ articles, the first name was also the corresponding author. In $17.6 \%(n=26)$ studies, the corresponding au-
Table 1. The total number of references given to the AJEM, AJEMCR, and TJEM in the articles published between 2010 and 2014 in the EAJEM and their distribution per article

\begin{tabular}{|l|l|c|c|c|}
\hline & EAJEM & JEMCR & TJEM & Total \\
\hline $\begin{array}{l}\text { Distribution within } \\
\text { total references } \\
\text { per thousand (n) }\end{array}$ & $\begin{array}{c}13.8 \% 0 \\
(41)\end{array}$ & $\begin{array}{c}1.1 \% \circ \\
(3)\end{array}$ & $\begin{array}{c}14.4 \% 0 \\
(43)\end{array}$ & $\begin{array}{c}29.3 \% 0 \\
(87)\end{array}$ \\
\hline $\begin{array}{l}\text { References per } \\
\text { article, \% (n) }\end{array}$ & $\begin{array}{c}27.7 \% \\
(41)\end{array}$ & $\begin{array}{c}2 \% \\
(3)\end{array}$ & $\begin{array}{c}29.1 \% \\
(43)\end{array}$ & $\begin{array}{c}58.8 \% \\
(87)\end{array}$ \\
\hline \multicolumn{4}{|l|}{$\begin{array}{l}\text { EAJEM: Eurasian Journal of Emergency Medicine (formerly known as the Academic } \\
\text { Journal of Emergency Medicine); JEMCR: Journal of Emergency Medicine Case }\end{array}$} \\
Reports; TJEM: Turkish Journal of Emergency Medicine \\
\hline
\end{tabular}

thor was the second name and in $6.8 \%(n=10)$, the corresponding author was the third name.

Original research most commonly had 3 keywords $(n=73$, $49.3 \%)$. This was followed by articles with 4 keywords ( $n=42,28.4 \%$ ), 5 keywords $(n=16,10.8 \%), 2$ keywords $(n=13,8.8 \%)$, and 6 keywords $(n=4,2.7 \%)$.

According to our findings, a total of 2981 references were used in the 148 articles that were examined: the median reference value per article was 17 ( $\min : 6$; max: 50). Here, 38 references were self-references (12.8\%) and 727 (24.4\%) references were citations of articles published in the journals in the Turkish index. Within all the references, the number of references to the TJEM was 43 (14.4\%); EAJEM, 41 (13.8\%); and AJEMCR, 3 (1.1\%). References per article to the TJEM were 43/148 (29.1\%); EAJEM, 41/148 (27.7\%); and AJEMCR, 3/148 (2\%) (Table 1).

The median value of the acceptance period of the articles was 49 days (mean: 64.1 \pm 55.3 ; min: 1; max: 350). The language, either Turkish or English, did not affect the acceptance period (the mean acceptance periods for Turkish and English were 62.8 \pm 61.1 and $65.4 \pm 49.8$, respectively; $p=0.782$ ). Whether an article was prospective $(65.7 \pm 53.8)$ or retrospective $(58.3 \pm 57.2)$, it had no effect on the acceptance period $(\mathrm{p}=0.498)$. 


\section{Discussion}

Our study is one of the leading bibliographic studies in the Turkey emergency medicine community. Using bibliometric methods, the topics studied, authors studying these topics, collaboration among authors, and topics with little or numerous studies within a particular discipline and particular country can be determined (3).

Bibliometric analyses provide the following benefits to the researcher:

- Providing information about the content of the journal,

- Selection of objectives relating to the planned publications,

- Revealing the academic effect.

In addition, it is effective for determining the research power of institutions and for developing research strategies (6).

Bibliometric methods and journal impact factors are also being used for purposes such as research evaluation, recruitment, academic promotion, research fund distribution, and publication support (7). At the same time, such a study can help in analyzing authors' trends and accumulation of academic publications, thereby providing guidance for the future. Research related to international publications by emergency medicine departments in Turkey is also available $(8,9)$.

The printed version of the EAJEM is being produced in limited numbers and is distributed free of charge to emergency medicine specialists and academics. In addition, the abstract and full texts of all articles can be obtained for free from the Web address www.eajem.com. The journal is indexed by the CINAHL, Gale/Cengage Learning, EBSCO, DOAJ, ProQuest, Index Copernicus, and TUBITAK ULAKBIM Turkish medical index (1). Also, as of 2016, it will start to be indexed in the Emerging Sources Citation Index (ESCl) database of Thomson Reuters and the printed publications will be viewable in the Web of Science (WoS) system (10). According to the data from TUBITAK, the number of Turkish journals indexed in the Thomson Reuters WoS scientific database is 70; here, 30 of these are journals have medical content (11).

The target audience of the magazine consists of emergency medicine specialists and faculty, researchers, specialists, assistants, general practitioners, and other healthcare personnel who conduct scientific studies and serve in the field of emergency medicine. The journal accepts research articles; reviews; case reports; editorial commentaries; letters to the editor; scientific letters; and articles related to training, original images, history, and publication ethics (1). The publication language, which was English and Turkish until 2014, was changed to English only thereafter in order to increase the journal's global recognition (12).

It is stated in the journal that within the context of editorial policies, articles on the most current topical headlines worldwide on the subject of emergency medicine are given priority. In addition, it is stated that papers on local and regional diseases, particularly those presenting different data than the information contained in the literature, are published (2). According to our study, the topics that found the least place in the EAJEM were disaster medicine $(n=5,3.4 \%)$ and pharmaceutical research $(n=6,4.1 \%)$. Therefore, due to the limited number of publications in these subjects, we assume that articles sent on these subjects will reach a higher level of acceptance.

Co-authoring is valuable in terms of enriching the article that is written by reflecting the different perspectives of individuals, as well as minimizing individual mistakes that can be overlooked by one person. At the same time, by bringing together experienced researchers and those who do not have much experience in the field of research, it contributes toward new names being introduced into the world of science and toward the quality of future research. The most important point to consider with respect to multi-authoring is to ensure that the list of authors does not include individuals whose contribution to the article is questionable $(13,14)$. The number of authors of original research articles published within the last 5 years in the EAJEM varied between 1 and 11, while articles with 6 authors were the most common. In our study, the total percentage of articles with 4, 5, 6, and 7 authors was $77 \%$.

While the number of references given to journals belonging to the Turkish medical index in articles with no emergency medicine resident and/or specialist among its authors was higher as compared to studies with at least one emergency physician among its authors, it was determined that the number of references given to Turkish emergency medicine journals (AJEMCR references + TEJM references + EAJEM references) was lower. The reason for this is that the publication history of emergency medicine journals is not as long as other Turkish medical index journals or that the article contents are not adequate for branches other than emergency medicine or that the authors chose their sources from their own fields.

One of the most important factors in ensuring that researchers are able to reach a published article is the keywords. Keywords appropriate to the article subject, in sufficient numbers, and provided with a standardized terminology carry great importance in making sure the article gets cited and contributes toward science (15). In our study, articles with 3 keywords were the most common; articles with 3 and 4 keywords comprise a majority (75\%) of all articles. Within the framework of article writing rules of the EAJEM, at least 3 and up to 6 keywords are required (16). It can be seen that authors have used the minimum required number of keywords. The use of more keywords by authors will facilitate access to their articles and increase recognition.

According to the writing guidelines of the EAJEM, the maximum number of references that can be used for research articles is 50 (16). There is no limitation on the number of references in two high-impact-factor international publications on emergency medicine, namely, the European Journal of Emergency Medicine (17) and the American Journal of Emergency Medicine (18). The journal Emergencias limits this number to 30 (19), while the Emergency Medicine Journal limits it to 25 (20). With 17 citations per article, the studies published in our journal maintained the number of keywords accepted by international journals.

Another association in Turkey related to emergency medicine is the Turkish Association of Emergency Medicine Specialists. The scientific publication organ of this association is the TJEM (21). In our study, the number of references given to the TJEM was 43 , while the number of references given to the EAJEM (self-reference) was 41 . These numbers are very close to each other, revealing that these two competitor associations support each other on the scientific platform.

One of the most critical decisions in the process of publication of a scientific study is determining the proposed publication journal. Since articles that are not evaluated and published on time lose their significance, authors who are going to send a publication pay attention to the acceptance period in their choice of journals $(14,22)$. In medical journals, the period of evaluation and acceptance can extend up to 1 year. Publications that are not accepted within this period will, no doubt, have a negative impact on their authors. It is stated that in several medical journals, this period can extend up to 4-6 months (22). In a study done in our country, it was determined that 
the period of acceptance varied between 0 and 12 months, but the most common period of acceptance was between 2 and 4 months (14). In our journal, the period of acceptance varied between 1 and 350 days, with an average of 49 days. Following this data, the editorial staff of the journal convened and limited the first evaluation period to 15 days.

\section{Conclusion}

Mainly retrospective articles are published in the EAJEM. We believe that in order for the journal to be scanned in higher-quality databases, the printing of prospective and multi-centric publications should be given preference. The number of keywords, which is an important parameter in reaching and referencing an article, being at the lower limit is an important problem. Only $29.3 \%$ references belong to Turkish emergency medicine journals. The number of original articles accepted from overseas is low.

Peer-review: Externally peer-reviewed.

Conflict of Interest: No conflict of interest was declared by the authors.

Financial Disclosure: The authors declared that this study has received no financial support.

\section{References}

1. Aims and Scope of Eurasian Journal of Emergency Medicine 2015. Available from: http://www.akademikaciltip.com/eng/sayfalar/8/Aims-andScope

2. Yildirim C. The Journal of Academic Emergency Medicine's Editorial Process and Manuscript Evaluation Process. Eurasian J Emerg Med 2012; 11: 135-6.

3. Zan BU. Türkiye'de bilim dallarında karşılaştırmalı bibliyometrik analiz çalışması. 2013.

4. McBurney MK, Novak PL, editors. What is bibliometrics and why should you care? Professional Communication Conference, 2002 IPCC 2002 Proceedings IEEE International; 2002: IEEE.

5. Tonta $\mathrm{Y}, \mathrm{Al}$ U. Türkiye'nin bilimsel yayın haritası: Türkiye'de dergi yayıncılığı üzerine bibliyometrik bir araştırma. Hacettepe Üniversitesi, 2007 TÜBITAK projesi: SOBAG-105K088 www tubitak gov tr. 2007.
6. Citation analysis and bibliometrics: University of York; 2015. Available from: https://www.york.ac.uk/library/info-for/researchers/citation/.

7. Tonta Y. Akademik Performans, Öğretim Üyeliğine Yükseltme ve Yayın Destekleme Ölçütleriyle Illgili Bir Değerlendirme (An Evaluation of Criteria on Academic Performance, Tenure and Publication Support). 2014.

8. Ersel M, Yürüktümen A, Özsaraç M, Kıyan S, Aksay E. Türkiye'deki Acil Tıp Anabilim Dalları'nın uluslararası yayın üretimi: 15. yıl değerlendirmesi. $\mathrm{Tr}$ J Emerg Med 2010; 10: 55-60.

9. Yanturalı S, Yürüktümen A, Aksay E, Çevik A. Türk Acil Tıp Anabilim Dalları'nın uluslararası yayın üretimi: Illk 10 yııın değerlendirilmesi. Türkiye Acil Tıp Dergisi 2004; 4: 170-3.

10. Serinken M. Editorial. Eurasian J Emerg Med 2015; 14: A-VIII.

11. ISI Web of Science (WoS)'da İndekslenen Türkiye Adresli Bilimsel Dergiler: TÜBiTAK Ulusal Akademik Ağ ve Bilgi Merkezi; 2013. Available from: http://ulakbim.tubitak.gov.tr/tr/hizmetlerimiz/isi-web-science-wosda-indekslenen-turkiye-adresli-bilimsel-dergiler.

12. Yıldırım C. Editorial. Eurasian J Emerg Med 2014; 3: A-VIII.

13. Al U, Soydal İ, Yalçın H. Bibliyometrik özellikleri açısından bilig'in değerlendirilmesi. Bilig 2010; 55: 1-20.

14. Halenur O, Altan A, Göztaş Z. Atatürk Üniversitesi Diş Hekimliği Fakültesi Dergisi'nin Bibliyometrik Analizi. Atatürk Üniversitesi Diş Hekimliği Fakültesi Dergisi 2015; 25(1).

15. Türkiye Atıf Dizini Yazım Kuralları 2015. Available from: http://www.atifdizini.com/standarts/tr-index.html.

16. Instructions for Authors. Available from: http://www.akademikaciltip. com/eng/sayfalar/3/Instructions-for-Authors.

17. European Journal of Emergency Medicine Online Submission and Review System, Instructions for Authors 2015. Available from: http://edmgr.ovid.com/ejem/accounts/ifauth.htm.

18. The American Journal of Emergency Medicine, Article Submissions 2015. Available from: http://www.ajemjournal.com/content/authorinfo\#idp1339440.

19. Instructions To Authors And Publication Policies 2015. Available from: http://emergencias.portalsemes.org/images/instructions_authors_ en.pdf.

20. Instructions for Authors, Original Articles. Available from: http://emj.bmj. com/site/about/guidelines.xhtml\#original_article.

21. About the Turkish Journal of Emergency Medicine 2015. Available from: http://www.trjemergmed.com/page.aspx?s=About-the-Journal.

22. Sipahi OR. Makale yayınlama sürecinde dergi seçimi. ANKEM Derg 2011; 25(Ek 2): 229-32. 